\title{
ANALISIS PENGARUH CITRA MEREK TERHADAP KEPUTUSAN MENGINAP DI HOTEL $X$
}

\author{
[Analysis The Effect Of Brand Image Towards Customer Decision Staying At \\ Hotel X]
}

\author{
Hari Iskandar, SE, MM \\ Program Studi Hospitality dan Pariwisata, Universitas Bunda Mulia \\ Diterima 29 Oktober 2020 / Disetujui 27 November 2020
}

\begin{abstract}
Hotel $X$ is a hotel that has good popularity, with many branches throughout Indonesia. This research aims to find out how hotel $X$ has brand image indicators affect the decision to stay at Hotel X.

This research method is quantitative. While the method of data analysis is multiple linear regression. Where the test uses SPSS software. The sample was taken by 135 respondents using a non probabilty sampling method, with purposive sampling techniques.

The results of the study were based on partial t tests of brand image variables including brand identity dimensions, brand association, and brand benefit and competence hypothesis accepted, which means that all three dimensions have an influence on variable $Y$, while the other two dimensions namely brand personality and brand attitude and behaviour where hypothesis is rejected which means there is no influence on variable $Y$. Based on the test results, the five dimensions of variable $X$ tested simultaneously have a significant influence on variable Y. Based on $R 2$ test results. , obtained a value of $64.6 \%$, of which $64.6 \%$ of brand image affects the decision to stay at Aston Hotel, and the remaining $35.4 \%$ is influenced by other variables outside $X$.

The conclusion of this study states that there is a positive influence of brand image on stay decisions of $64.6 \%$ while $35.4 \%$ is influenced by other variables. Advice in terms of brand personality is to improve the characteristics of the service, then keep the room to fit the picture displayed, in terms of brand attitude and behaviour can pay more attention to the facilities provided in normal condition, both in the form of food and service given professionally.
\end{abstract}

Keywords: Brand, image, Hotel, Customer Decision

\begin{abstract}
ABSTRAK
Hotel X memiliki citra merek yang baik dimana dengan meningkatnya tingkat hunian kamar yang baik disetiap periode. Peneliti melakukan penelitian ini dengan tujuan untuk mengetahui pengaruh dari indikator brand image Hotel X terhadap keputusan tamu untuk menginap.. Metode kuantitatif digunakan sebagai metode penelitian, dan analisis data yakni regresi linear sederhana. Dimana uji penelitian ini menggunakan SPSS. Sampel yang diambil sebanyak 135 responden menggunakan metode non probabilty sampling, dengan teknik purposive sampling.

Hasil penelitian berdasarkan uji t dari variabel brand image diantaranya dimensi brand identity, brand association, dan brand benefit and competence hipotesis diterima, yang berarti ketiga dimensi tersebut memilik pengaruh terhadap variabel Y, sedangkan kedua dimensi lainnya yaitu brand personality dan brand attitude and behaviour dimana hipotesis ditolak yang berarti tidak terdapat pengaruh terhadap variabel Y. Berdasarkan hasil uji $\mathrm{F}$, variabel $\mathrm{X}$ diuji secara simultan memiliki pengaruh yang signifikan terhadap variabel $\mathrm{Y}$. Berdasarkan hasil uji R2, diperoleh nilai sebesar 64,6\%, dimana sebesar 64,6\% brand image berpengaruh terhadap keputusan menginap di Hotel Aston, dan sisanya yaitu 35,4\% dipengaruhi oleh variabel lain diluar X.

Kesimpulan yang bisa didapatkan bahwa terdapat pengaruh positif dari brand image terhadap keputusan menginap sebesar $64,6 \%$ sedangkan 35,4\% dipengaruhi oleh variabel lainnya. Saran yang bisa diberikan adalah meningkatkan karakteristik dari service-nya, dan juga menjaga kamar agar sesuai dengan gambar yang ditampilkan, dari sisi brand attitude and behaviour dapat lebih memperhatikan fasilitas yang disediakan dalam kondisi normal, baik dalam bentuk makanan dan service diberikan secara profesional.
\end{abstract}

Kata Kunci: Merk, Citra, Hotel, Keputusan Menginap. 


\section{PENDAHULUAN}

\section{Latar Belakang}

Pengertian hotel menurut American Hotel and Association, hotel adalah suatu tempat yang berniat disiapkan untuk tujuan pengianapan, makan dan minum serta failitas lainnya yang terdapat pada berupa fasilitas hotel lainnya. Menurut Sulastiyono dalam penelitian Ruri Indra Irwansyah (2017) hotel adalah suatu perusahaan yang dikelola oleh pemiliknya, dengan menyediakan pelayanan makanan, minuman dan fasilitas kamar untuk tidur kepada orang-orang yang melakukan perjalanan dan mampu membayar dengan jumlah yang wajar sesuai dengan pelayanan yang diterima tanpa adanya perjanjian khusus.

Menurut Silvita Agmasari pada travel.kompas.com yang dipublikasikan pada tanggal 7 Oktober 2010, Hotel Indonesia yang terletak di Jalan $\mathrm{MH}$ Thamrin telah menjadi dasar terkenalnya istilah hotel bintang di Indonesia, yang diresmikan pada tanggal 5 Agustus 1962. Hotel Indonesia pada masanya merupakan hotel termegah di Asia Tenggara dan menjadi roda penggerak bermunculannya hotel-hotel baru setiap tahunnya di Indonesia hingga saat ini. Dengan meningkatnya pendapatan devisi sektor pariwisata Indonesia semakin banyaknya akomodasi yang bertumbuh, maka dari itu banyak bermunculan hotel chain (jejaring) grup lokal di Indonesia. Mulai dari Accor, Starwood Hotels, InterContinental Hotels Group, Swiss-Belhotel, Tauzia Management, dan Archipelago International Group.

Menurut Badan Pusat Statistik yang dikeluarkan di tahun 2018, jumlah penyedia usaha di Indonesia pada tahun 2018 tercatat sebanyak 28.230 usaha dengan jumlah kamar tersedia mencapai 712.202 kamar. Diantara usaha akomodasi tersebut, 3.314 usaha $(11,74 \%)$ merupakan hotel-hotel yang telah diklasifikasikan sebagai hotel berbintang dengan jumlah kamar sebanyak 278.522 unit.

*Korespondensi Penulis:

E-mail: hiskandar@bundamulia.ac.id
Di Indonesia terdapat banyak berbagai macam merk/brand hotel mulai dari International chain hotel, local chain hotel dan Independent Hotel yang dimana mereka terbagi menjadi beberapa klasifikasi hotel bintang sesuai dengan peruntukan nya masing masing. Pada tahun 2018 jumlah hotel berbintang yang terbanyak adalah hotel bintang tiga, yaitu 1.302 usaha (39,29 persen) dengan 100.119 kamar (35,95 persen) diikuti hotel bintang dua sebanyak 745 usaha $(22,48$ persen) dengan jumlah kamar sebanyak 48.137 kamar (17,28 persen). Di urutan ke tiga hotel bintang empat sebanyak 682 hotel (20,58 persen) dengan jumlah kamar 84.104 kamar $(30,20$ persen). Hotel X memiliki data tingkat hunian sebagai berikut:

Tabel 1. Data Occupancy Hotel

\begin{tabular}{cccc}
\hline 2018 & $\begin{array}{c}\text { Room } \\
\text { Occ }\end{array}$ & 2019 & Room Occ \\
\hline Jan & 47,48 & Jan & 40,23 \\
\hline Feb & 38,04 & Feb & 45,55 \\
\hline Mar & 50,88 & Mar & 43,85 \\
\hline Apr & 54,90 & Apr & 52,20 \\
\hline May & 45,82 & May & 33,39 \\
\hline Jun & 49,35 & Jun & 65,06 \\
\hline Jul & 76,14 & Jul & 70,16 \\
\hline Aug & 63,69 & Aug & 55,71 \\
\hline Sep & 49,03 & Sep & 50,51 \\
\hline Oct & 74,38 & Oct & 44,97 \\
\hline Nov & 71,06 & Nov & 63,55 \\
\hline Dec & 68,79 & Dec & 69,50
\end{tabular}

Sumber: data yang dikelola Hotel

Dari data room occupancy diatas, dapat dilihat terjadi penurunan dari tahun 2018 sebesar $57,46 \%$ menjadi $52.89 \%$ di tahun 2019.

Brand Image menurut Tjiptono (2014), memiliki beberapa maanfaat yaitu, manfaat ekonomi, manfaat fungsional, dan manfaat psikologis. Dimana ketiga manfaat ini mempengaruhi perusahaan dalam menjual produknya kepada konsumen dan membuat konsumen memutuskan untuk membeli produk tersebut.

Berdasarkan bebarapa uraian yang telah dipaparkan di atas, maka peneliti tertarik melakukan penelitian mengenai “ANALISIS PENGARUH CITRA MERK 


\section{TERHADAP KEPUTUSAN MENGINAP DI HOTEL $X$ ”. \\ Identifikasi Masalah}

Berdasarkan latar belakang masalah diatas, penulis melihat banyaknya perkembangan hotel yang signifikan tiap tahun dan berbagai macam merk hotel yang berdatangan terutama di Indonesia. Untuk itu, penulis ingin melihat pengaruh citra merk dari hotel $\mathrm{X}$ mempengaruhi keputusan menginap dari sisi customer (tamu).

\section{Tujuan dan Manfaat Penelitian}

Tujuan dari penelitian ini adalah:

A. Penelitian ini bertujuan untuk mengetahui terdapat pengaruh variabel brand image terhadap keputusan menginap di Hotel X

B. Menganalisis dimensi dari brand image yaitu brand identity, brand personality, brand association, brand attitude and behavior brand benefit and competence mempunyai pengaruh secara parsial terhadap keputusan menginap di Hotel X.

Manfaat dari penelitian adalah:

1. Untuk perusahaan hasil penelitian ini diharapkan dapat memberikan masukan bagi manajemen hotel untuk tetap menjaga citra perusahaan/ merk dagang dalam upaya mempengaruhi keputusan menginap.

2. Untuk civitas akademika hasil penelitian ini diharapkan dapat berguna sebagai bahan penelitian dan masukan bagi penelitian - penelitian selanjutnya yang berkaitan dengan keputusan pembelian/menginap.

3. Bagi peneliti, penelitian ini dapat digunakan untuk menambah pemikiran keilmuan serta pengalaman dalam menganalisis permasalahan khususnya dibidang keputusan pembelian/menginap.

\section{METODE PENELITIAN}

Pada penelitian ini peneliti menggunakan metode kuantitatif dengan menyebarkan kuesioner (angket) tertutup dimana soal/ pernyataan yang dibuat sudah ditentukan sehingga mempermudah responden dalam menjawab dan mempermudah peneliti untuk menarik kesimpulan dari hasil kuesioner yang didapatkan. Kuesioner ini dibuat dengan menggunakan Google Form, dimana responden hanya perlu mengisi salah satu jawaban dari tiap soal dan tidak ada jawaban diluar dari pilihan jawaban yang disediakan.Total responden berjumlah 135 responden dimana menggunakan rumus dari Hair et al. yang menyatakan jumlah indikator $\mathrm{x} 5$.

Dalam penelitian ini akan menguji secara simultan variable citra merk (brand image) dan secara parsial dari dimensi citra merk terhadap minat menginap tamu di hotel $\mathrm{X}$. Untuk pengukuran skor menggunakan skala likert dengan 5 pilihan yaitu:

Tabel 2. Skala Likert

\begin{tabular}{cc}
\hline Skor & Penilaian \\
\hline 5 & Sangat Setuju (SS) \\
\hline 4 & Setuju (S) \\
\hline 3 & Ragu-Ragu (RR) \\
\hline 2 & Tidak Setuju (TS) \\
\hline 1 & Sangat Tidak Setuju (STS)
\end{tabular}

Sumber : Sugiyono 2018

Untuk Responden penelitian adalah semua tamu yang pernah menginap minimal 1 (satu) kali di hotel $\mathrm{X}$ dan merasakan pengalaman nya bermalam sehingga mereka bisa memberikan pendapat melalui kuesioner. Data yang didapatkan lalu diolah menggunakan SPSS versi 25 dan disajikan secara singkat, jelas, dan informatif melalui uji validitas, reliabilitas, regresi linier berganda, analisis koefisien determinasi, uji $\mathrm{T}$ dan Uji F.

Tabel 3. Operasional Variabel X

\begin{tabular}{|c|c|c|c|}
\hline $\begin{array}{c}\text { Variab } \\
\text { el }\end{array}$ & $\begin{array}{c}\text { Dimen } \\
\text { si }\end{array}$ & Indikator & $\begin{array}{c}\text { Skala } \\
\text { Penguj } \\
\text { ian }\end{array}$ \\
\hline \multirow{5}{*}{$\begin{array}{c}\text { Brand } \\
\text { Image } \\
\mathrm{X} \\
\text { Kotler } \\
\text { dan }\end{array}$} & \multirow{5}{*}{$\begin{array}{c}\text { Brand } \\
\text { Identit } \\
y\end{array}$} & Reputasi & \multirow{5}{*}{$\begin{array}{c}\text { Skala } \\
\text { Likert }\end{array}$} \\
\hline & & Merek & \\
\hline & & Relevansi & \\
\hline & & Merek & \\
\hline & & Kepribadian & \\
\hline
\end{tabular}


Versi Online: https://journal.ubm.ac.id/index.php/hospitality-pariwisata DOI : dx.doi.org/10.30813/.v6i2.2417

\begin{tabular}{|c|c|c|}
\hline \multirow{25}{*}{$\begin{array}{l}\text { Keller } \\
(2013)\end{array}$} & & Merek \\
\hline & & $\begin{array}{c}\text { Hubungan } \\
\text { Merek }\end{array}$ \\
\hline & & Kinerja Merek \\
\hline & & Sincerity \\
\hline & Brand & Excitement \\
\hline & Person & Competence \\
\hline & ality & Sophistication \\
\hline & & Ruggedness \\
\hline & & Product \\
\hline & & Attributes \\
\hline & Brand & Costumer's \\
\hline & Associ & Benefit \\
\hline & ation & Relative Price \\
\hline & & Application \\
\hline & & Life Style \\
\hline & Brand & Tertarik \\
\hline & Attitud & Percaya \\
\hline & $\begin{array}{c}\text { Behavi } \\
\text { or }\end{array}$ & Kesan Positif \\
\hline & & $\begin{array}{c}\text { Merek terbaik } \\
\text { untuk ketegori } \\
\text { produk }\end{array}$ \\
\hline & & Kinerja yang \\
\hline & Brand & lebih baik \\
\hline & $\begin{array}{c}\text { Benefit } \\
\text { and }\end{array}$ & $\begin{array}{c}\text { dibandingkan } \\
\text { merek lain }\end{array}$ \\
\hline & Compe & Efektif \\
\hline & tence & $\begin{array}{l}\text { dibandingkan } \\
\text { merek lain }\end{array}$ \\
\hline & & $\begin{array}{l}\text { Dapat } \\
\text { memenuhi } \\
\text { kebutuhan }\end{array}$ \\
\hline
\end{tabular}

Sumber : Kotler dan Keller (2013)

Tabel 4. Operasional Variabel Y

\begin{tabular}{cccc}
\hline $\begin{array}{c}\text { Variabe } \\
1\end{array}$ & Dimensi & Indikator & $\begin{array}{c}\text { Skala } \\
\text { Penguk } \\
\text { uran }\end{array}$ \\
\cline { 1 - 3 } $\begin{array}{c}\text { Keputu } \\
\text { san } \\
\text { Mengin } \\
\text { ap }\end{array}$ & $\begin{array}{c}\text { Necogniti } \\
\text { on }\end{array}$ & $\begin{array}{c}\text { produk } \\
\text { utama yang } \\
\text { dipilih }\end{array}$ & \\
\cline { 2 - 3 } Y & Informati & kemudahan & \\
on & Eksploratif & Skala \\
Kotler, & Search & and & Likert \\
P., \& & & reservasi & \\
G. & Evaluatio & Memiliki & \\
Armstr & nof & nilai yang & \\
ong. & alternativ & sesuai/seba & \\
& & &
\end{tabular}

\begin{tabular}{|c|c|c|}
\hline \multirow[t]{3}{*}{ (2016) } & es & nding \\
\hline & $\begin{array}{l}\text { Purchase } \\
\text { Decision }\end{array}$ & $\begin{array}{l}\text { kerpercayaa } \\
\mathrm{n} \text { terhadap } \\
\text { brand }\end{array}$ \\
\hline & $\begin{array}{l}\text { Postpurc } \\
\text { hase } \\
\text { Behavior }\end{array}$ & $\begin{array}{l}\text { Minat } \\
\text { transaksi } \\
\text { dimasa } \\
\text { yang akan } \\
\text { datang }\end{array}$ \\
\hline
\end{tabular}

Sumber: Kotler, P., \& G. Armstrong (2016)

adalah:

Uji Hipotesis dalam penelitian ini

Hipotesis Simultan

Brand Image $(\mathrm{X})$

$\mathrm{H} 0$ : Tidak terdapat pengaruh brand image terhadap keputusan menginap di Hotel $\mathrm{X}$

$\mathrm{H} 1$ : Terdapat pengaruh brand image terhadap keputusan menginap di Hotel X

\section{Hipotesis Parsial}

1. Dimensi brand identity

H0 : Tidak terdapat pengaruh dimensi brand identity terhadap keputusan menginap di Hotel X

H1 : Terdapat pengaruh dimensi brand identity terhadap keputusan menginap di Hotel X

2. Dimensi brand personality

H0 : Tidak terdapat pengaruh dimensi brand personality terhadap keputusan menginap di Hotel $\mathrm{X}$

H1 : Terdapat pengaruh dimensi brand personality terhadap keputusan menginap di Hotel X

3. Dimensi brand association

H0 : Tidak terdapat pengaruh dimensi brand association terhadap keputusan menginap di Hotel $\mathrm{X}$

H1 : Terdapat pengaruh dimensi brand association terhadap keputusan menginap di Hotel X

4. Dimensi brand attitude and behavior

H0 : Tidak terdapat pengaruh dimensi brand attitude and behavior terhadap keputusan menginap di Hotel $\mathrm{X}$

H1 : Terdapat pengaruh dimensi brand attitude and behavior terhadap keputusan menginap di Hotel X

5. Dimensi brand benefit and competence 
H0 : Tidak terdapat pengaruh dimensi brand benefit and competence terhadap keputusan menginap Hotel $\mathrm{X}$

H1 : Terdapat pengaruh dimensi brand benefit and competence terhadap keputusan menginap di Hotel X.

\section{HASIL DAN PEMBAHASAN}

\section{Profile Responden}

Dalam penelitian ini melibatkan 135 responden yang menjadi sampel, yang diambil berdasarkan responden yang pernah menginap. Berikut adalah bagan karakteristik responden, yang digolongkan berdasarkan jenis kelamin, usia, pekerjaan, lokasi, dan penghasilan.

\section{Jenis Kelamin}

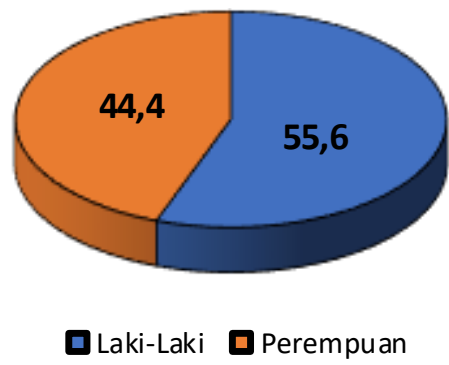

\section{Gambar 1. Grafik Responden Berdasarkan Jenis Kelamin \\ Sumber : Data diolah peneliti, 2020}

Berdasarkan hasil pengolahan data, dapat disimpulkan bahwa mayoritas konsumen yang pernah menginap adalah lakilaki $(55,60 \%)$, sedangkan konsumen perempuan hanya $44,40 \%$.

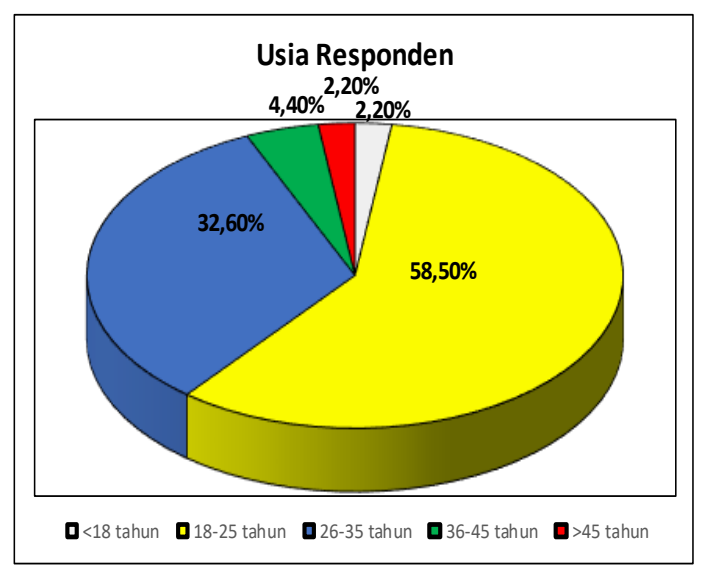

\section{Gambar 2. Grafik Responden} Berdasarkan Usia

Sumber : Data diolah peneliti, 2020

Said (2015) memaparkan bahwa umur 15 tahun sudah termasuk kedalam kategori remaja menengah dan dianggap telah mampu mengerti dan menjawab secara rinci. Sehingga peneliti membataskan untuk usia dibawah 18 tahun dengan batas minimal 15 tahun sudah boleh mengisi kuesioner tersebut.

Berdasarkan hasil pengolahan data, dapat disimpulkan bahwa dari keseluruhan responden sebanyak 135 orang, dapat dilihat dari segi usia, bahwa usia responden yang paling banyak adalah direntang umur 18-25 tahun yang merupakan usia produktif, dimana sebesar $58,50 \%$, kemudian kedua terbesar ada di usia 26-35 tahun sebesar $32,60 \%$, sisanya ada di 4,40\% untuk usia 36-45 tahun, 2,20\% usia diatas 45 tahun dan yang terakhir 2,20\% untuk usia dibawah 18 tahun. Dari grafik diatas dapat dilihat bahwa mayoritas responden berusia 18-25 dan 26-35 tahun, dimana kemungkinan sudah memiliki pendidikan tinggi, dan penghasilan yang cukup baik hingga memiliki kemampuan untuk menginap di hotel.

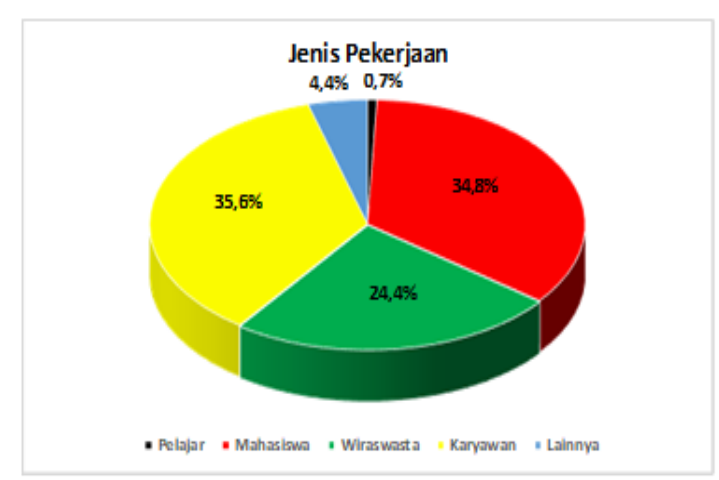

Gambar 3. Grafik Responden Berdasarkan Pekerjaan

Sumber : Data diolah peneliti, 2020

Berdasarkan hasil data yang telah diolah, bahwa sebanyak 35,6\% responden merupakan karyawan, kemudian $34,8 \%$ mahasiswa, selanjutnya $24,4 \%$ merupakan wiraswasta, dan $4,4 \%$ responden lainnya (ibu rumah tangga, pensiun), serta sisanya sebesar $0,7 \%$ merupakan pelajar. Sehingga dapat disimpulkan bahwa jenis pekerjaan yang paling dominan adalah karyawan yang 
dimana sudah berpenghasilan dan memiliki keputusannya sendiri untuk menentukan keputusan menginap. Disusul mahasiswa yang diman sebesar $34,8 \%$ ini rata-rata yang sudah pernah bekerja dan memiliki penghasilannya sendiri sehingga mereka tidak keberatan untuk mengeluarkan uang untuk menginap di Hotel X.

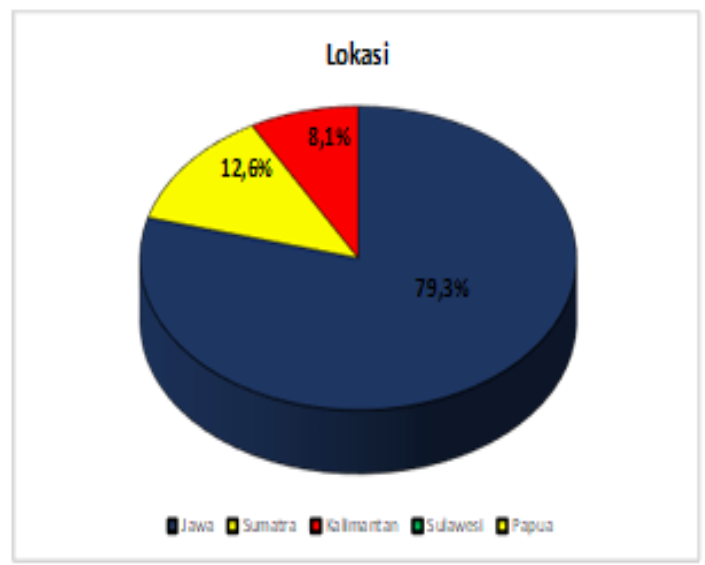

Gambar 4. Grafik Responden Berdasarkan Lokasi

Sumber : Data diolah peneliti, 2020

Berdasarkan hasil pengolahan data sebanyak 135 responden, dari 5 lokasi yang disediakan hanya 3 lokasi yang terisi, yaitu sebesar 79,3\% responden menjawab berlokasi di Pulau Jawa, hal ini menunjukan bahwa mayoritas responden tinggal di pulau Jawa. Kemudian selanjutnya bertempat tinggal di Sumatra sebesar $12,6 \%$, dan yang terakhir berlokasi di Pulau Kalimantan dimana sebesar $8,1 \%$.

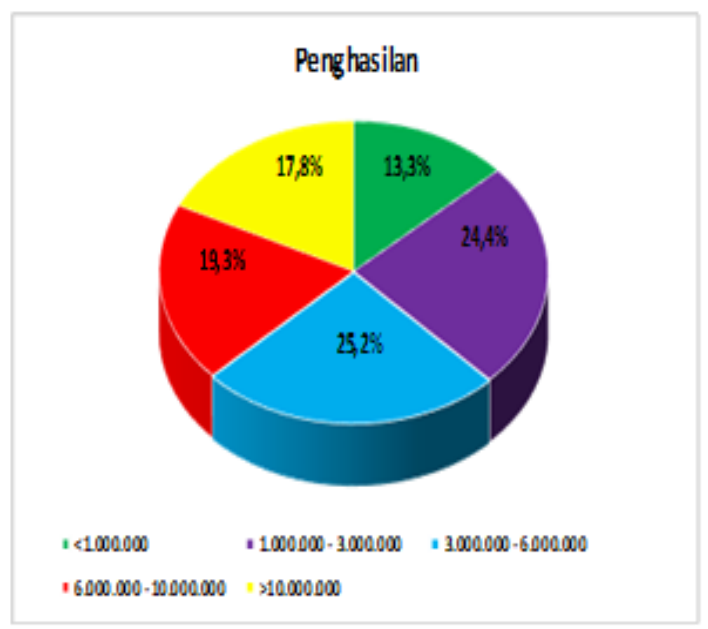

\section{Gambar 5. Grafik Responden Berdasarkan Penghasilan \\ Sumber : Data diolah peneliti, 2020}

Dari data yang didapatkan sebanyak 135 responden, penghasilan responden beragam dan merata, dapat dilihat untuk grafik terbesar terdapat pada penghasilan di kisaran Rp. 3.000.000 - Rp. 6.000 .000 sebesar 25,2\%, kemudian hanya berbeda sedikit di kisaran Rp. 1.000 .000 - Rp. 3.000 .000 sebesar $24,4 \%$. Selanjutnya untuk kisaran Rp 6.000.000 - 10.000.000 sebesar 19,3\%, dan dibawah Rp. 1.000 .000 sebesar $13,3 \%$ serta yang terakhir dengan penghasilan diatas Rp. 10.000.000 sebesar 17,8\%. Dari grafik diatas dapat disimpulkan bahwa Hotel $\mathrm{X}$ memiliki customer dari tingkat penghasilan yang beragam, dimana paling dominan adalah disekitar Rp. 3.000.000 - Rp. 6.000.000 sejalan dengan harga kamar dari Hotel $\mathrm{X}$ yang dikisaran Rp. $400 \mathrm{rb}$ an permalam, hingga jutaan tergantung dari lokasi hotel, bintang hotel, dan jenis kamar yang dipilih.

\section{Uji Validitas}

Dalam penelitian ini dilakukan uji validitas dan realibilitas menggunakan SPSS 25 sebanyak 30 sampel. Dimana menurut Sugiyono (2017) menyatakan bahwa jika koefisian antara item dengan total item sama atau di atas 0,3 maka item tersebut dinyatakan valid, tetapi jika nilai korelasinya dibawah 0,3 maka item tersebut dinyatakan tidak valid.

Menurut tabel kolerasi product moment Zar (1984) dalam Lehner (1996), standar $\mathrm{r}$ tabel bagi 30 sampel untuk tingkat signifikan 0,05 adalah $\mathrm{df}=\mathrm{n}-2$, berarti $30-2$ $=68(0,361)$ di $\mathrm{r}$ tabelnya. Jadi, dalam penelitian ini, dapat dikatakan valid apabila $r$ hitung $>0,361$.

Tabel 5. Hasil uji Validitas Variabel $X$

\begin{tabular}{ccccc}
\hline No. & $\begin{array}{c}\text { Nama } \\
\text { Variabel }\end{array}$ & $\begin{array}{c}\mathbf{R} \\
\text { Hitung }\end{array}$ & $\begin{array}{c}\mathbf{R} \\
\text { Tabel }\end{array}$ & $\begin{array}{c}\text { Ketera } \\
\text { ngan }\end{array}$ \\
\hline $\mathbf{1}$ & $\begin{array}{c}\text { Brand } \\
\text { Identity 1 }\end{array}$ & 0,669 & 0,361 & VALID \\
\hline $\mathbf{2}$ & $\begin{array}{c}\text { Brand } \\
\text { Identity 2 }\end{array}$ & 0,741 & 0,361 & VALID \\
\hline $\mathbf{3}$ & $\begin{array}{c}\text { Brand } \\
\text { Identity 3 }\end{array}$ & 0,654 & 0,361 & VALID \\
\hline $\mathbf{4}$ & Brand & 0,840 & 0,361 & VALID \\
\hline
\end{tabular}


Versi Online: https://journal.ubm.ac.id/index.php/hospitality-pariwisata DOI : dx.doi.org/10.30813/.v6i2.2417

\begin{tabular}{|c|c|c|c|c|}
\hline & Identity 4 & & & \\
\hline 5 & $\begin{array}{c}\text { Brand } \\
\text { Identity } 5\end{array}$ & 0,850 & 0,361 & VALID \\
\hline 6 & $\begin{array}{c}\text { Brand } \\
\text { Personali } \\
\text { ty } 1\end{array}$ & 0,518 & 0,361 & VALID \\
\hline 7 & $\begin{array}{c}\text { Brand } \\
\text { Personali }\end{array}$ & 0,816 & 0,361 & VALID \\
\hline
\end{tabular}

\begin{tabular}{ccccc}
\multicolumn{6}{c}{ ty 2 } & Brand & 0,772 & 0,361 & VALID \\
& $\begin{array}{c}\text { Personali } \\
\text { ty 3 }\end{array}$ & & & \\
\hline $\mathbf{9}$ & $\begin{array}{c}\text { Brand } \\
\text { Personali }\end{array}$ & 0,761 & 0,361 & VALID \\
& & &
\end{tabular}

ty 4

\begin{tabular}{ccccc}
\hline $\mathbf{1 0}$ & $\begin{array}{c}\text { Brand } \\
\text { Personali } \\
\text { ty 5 }\end{array}$ & 0,614 & 0,361 & VALID \\
\hline $\mathbf{1 1}$ & $\begin{array}{c}\text { Brand } \\
\text { Associati } \\
\text { on 1 }\end{array}$ & 0,764 & 0,361 & VALID \\
\hline $\mathbf{1 2}$ & $\begin{array}{c}\text { Brand } \\
\text { Associati } \\
\text { on 2 }\end{array}$ & 0,832 & 0,361 & VALID \\
\hline $\mathbf{1 3}$ & $\begin{array}{c}\text { Brand } \\
\text { Associati } \\
\text { on 3 }\end{array}$ & 0,557 & 0,361 & VALID \\
\hline $\mathbf{1 4}$ & Brand & 0,524 & 0,361 & VALID
\end{tabular}

\begin{tabular}{ccccc}
\hline $\mathbf{1 4}$ & $\begin{array}{c}\text { Brand } \\
\text { Associati } \\
\text { on 4 }\end{array}$ & 0,524 & 0,361 & VALID \\
\hline $\mathbf{1 5}$ & Brand & 0,833 & 0,361 & VALID
\end{tabular}

Associati

\begin{tabular}{ccccc}
\multicolumn{6}{c}{ on 5} & & & \\
\hline $16 \quad$ Brand & 0,881 & 0,361 & VALID \\
& Attitude \\
and & & & \\
& & & &
\end{tabular}

Behavior

\begin{tabular}{|c|c|c|c|c|}
\hline & 1 & & & \\
\hline 17 & $\begin{array}{l}\text { Brand } \\
\text { Attitude }\end{array}$ & 0,816 & 0,361 & VALID \\
\hline
\end{tabular}

\begin{tabular}{ccccc}
\multicolumn{6}{c}{2} & & & \\
\hline & Brand & 0,821 & 0,361 & VALID \\
& Attitude & & & \\
and & & & \\
& Behavior \\
& 3 & & & \\
\hline 19 & Brand & 0,651 & 0,361 & VALID \\
& Benefit & & & \\
and & & & \\
& Compete & & & \\
\hline
\end{tabular}

\begin{tabular}{|c|c|c|c|c|}
\hline & nce 1 & & & \\
\hline 20 & $\begin{array}{l}\text { Brand } \\
\text { Benefit } \\
\text { and } \\
\text { Compete } \\
\text { nce } 2\end{array}$ & 0,898 & 0,361 & VALID \\
\hline 21 & $\begin{array}{c}\text { Brand } \\
\text { Benefit } \\
\text { and } \\
\text { Compete } \\
\text { nce } 3\end{array}$ & 0,918 & 0,361 & VALID \\
\hline 22 & $\begin{array}{c}\text { Brand } \\
\text { Benefit } \\
\text { and } \\
\text { Compete } \\
\text { nce } 4\end{array}$ & 0,721 & 0,361 & VALID \\
\hline
\end{tabular}

Berdasarkan hasil pengolahan data SPSS 25, semua variabel $X$ yakni variabel X1 (Brand Identity), X2 (Brand Personality), X3 (Brand Association), X4 (Brand Attitude and Behavior), dan X5 (Brand Benefit and Competence). Dinyatakan bersifat valid, karena semua $\mathrm{R}$ hitung > $\mathrm{R}$ tabel $(0,361)$.

\section{Tabel 6. Hasil Uji Validitas Y}

\begin{tabular}{|c|c|c|c|c|}
\hline No. & $\begin{array}{c}\text { Nama } \\
\text { Variabel }\end{array}$ & $\begin{array}{c}\mathrm{R} \\
\text { Hitung }\end{array}$ & $\begin{array}{c}\mathrm{R} \\
\text { Tabel }\end{array}$ & Keterangan \\
\hline 1 & $\begin{array}{c}\text { Keputusan } \\
\text { Menginap } \\
1\end{array}$ & 0,801 & 0,361 & VALID \\
\hline 2 & $\begin{array}{c}\text { Keputusan } \\
\text { Menginap } \\
2\end{array}$ & 0,761 & 0,361 & VALID \\
\hline 3 & $\begin{array}{c}\text { Keputusan } \\
\text { Menginap } \\
3\end{array}$ & 0,887 & 0,361 & VALID \\
\hline 4 & $\begin{array}{c}\text { Keputusan } \\
\text { Menginap } \\
4\end{array}$ & 0,795 & 0,361 & VALID \\
\hline 5 & $\begin{array}{c}\text { Keputusan } \\
\text { Menginap } \\
5\end{array}$ & 0,817 & 0,361 & VALID \\
\hline
\end{tabular}

Berdasarkan hasil pengolahan data SPSS 25, data pada variabel Y yakni variabel keputusan menginap dinyatakan valid, karena semua R hitung > R tabel (0,361). Dengan 
demikian, semua variabel $\mathrm{X}$ dan $\mathrm{Y}$ telah bersifat valid, maka dapat dilanjutkan ke uji selanjutnya, yaitu uji reliabilitas.

\section{Uji Realibilitas}

Dasar pengambilan keputusan ini adalah apabila Cronbach's Alpha lebih besar $(>)$ dari $0,60=$ Reliabel. Jika Alpha lebih kecil $(<)$ dari 0,60 = Tidak Reliabel (Siregar, 2013).

\section{Tabel 7. Hasil uji Realibilitas}

Reliability Statistics

\begin{tabular}{ccl}
\hline $\begin{array}{c}\text { Cronchbach's } \\
\text { Alpha }\end{array}$ & $\begin{array}{c}\text { N of } \\
\text { items }\end{array}$ & Dimensi \\
\hline 0,807 & 5 & $\mathrm{X} 1$ \\
\hline 0,716 & 5 & $\mathrm{X} 2$ \\
\hline 0,726 & 5 & $\mathrm{X} 3$ \\
\hline 0,790 & 3 & $\mathrm{X} 4$ \\
\hline 0,817 & 4 & $\mathrm{X} 5$ \\
\hline 0,816 & 5 & $\mathrm{Y}$
\end{tabular}

Setelah semua variabel dilakukan uji reliabilitas, didapatkan hasil bahwa semua variabel tersebut bersifat reliabel dikarenakan melebihi dari 0,6 .

\section{Koefisien Determinasi $\left(\mathbf{R}^{\mathbf{2}}\right)$}

$$
\text { Menurut Sugiyono }
$$

berdasarkan perhitungan koefisien korelasi, maka dapat dihitung koefisien determinasi dengan rumus, sebagai berikut $K D=R^{2} x$ $100 \%$ Keterangan KD $=$ Koefisien Determinasi, $\mathrm{R}^{2}=$ Koefisien Korelasi.

Tabel 8. Koefisien Determinasi $\left(\mathbf{R}^{2}\right)$ Model Summary

\begin{tabular}{|c|c|c|c|}
\hline Model & $\mathrm{R}$ & $\begin{array}{cc}\mathrm{R} & \text { Adjusted } \mathrm{R} \\
\text { Square } & \text { Square }\end{array}$ & $\begin{array}{l}\text { Std. Error } \\
\text { of the } \\
\text { Estimate }\end{array}$ \\
\hline 1 & $.804^{a}$ & .632 & 1.513 \\
\hline \multicolumn{4}{|c|}{$\begin{array}{l}\text { a. Predictors: (Constant), Brand Benefit and } \\
\text { Competence, Brand Identity, Brand Association, } \\
\text { Brand Personality, Brand Attitude and Behavior }\end{array}$} \\
\hline
\end{tabular}

Dalam hasil penelitian ini, terlihat angka $\mathrm{R}^{2}$ yaitu 0,646 . Hal ini berarti sebanyak $64,6 \%$ keputusan menginap konsumen dipengaruhi oleh variabel X (Brand Image)
Sementara sisanya yaitu 35,4\% dipengaruhi oleh variabel-variabel lain diluar variabel $\mathrm{X}$.

\section{Uji t}

Dasar pengambilan keputusan untuk uji t menurut Ghozali (2016) adalah pada dasarnya menunjukan seberapa jauh pengaruh satu variabel independen secara individual dalam menerangkan variasi variabel dependen.

Menurut Ghozali (2016), tingkat signifikansi $\alpha=0,05$. Pengujian hipotesis dengan menggunakan uji t, jika signifikansi $<0,05$ maka H0 ditolak, jika tingkat signifikansi >0,05 maka H0 diterima. Maka Hipotesis alternatif diterima, yang menyatakan bahwa suatu variabel independen secara individual dan signifikan mempengaruhi variabel dependen.

\section{Tabel 9. Hasil Uji T}

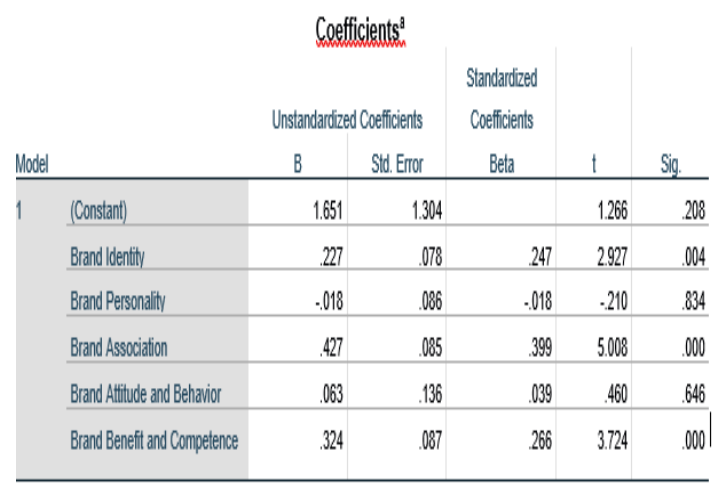

a. Dependent Variable: Keputusan Pembelian

Sumber : Data diolah peneliti dengan SPSS 25, 2020

Diketahui nilai Sig. untuk pengaruh $\mathrm{X}_{1}$ terhadap $\mathrm{Y}$ adalah sebesar $0,004<0,05$ dan nilai $t_{\text {hitung }} 2,927>t_{\text {tabel }} 1,97852$, sehingga dapat disimpulkan bahwa $\mathrm{H} 0$ ditolak dan $\mathrm{H} 1$ diterima yang berarti terdapat pengaruh secara parsial dimensi X1 (Brand Identity) terhadap Y (Keputusan Menginap). Hal ini disebabkan dalam menentukan keputusan menginap di Hotel $X, \quad$ konsumen memperhatikan Brand Identity. dimensi X1 (Brand Identity) berperan dalam menentukan keputusan menginap di Hotel X.

Dimensi $\mathrm{X}_{2} \quad$ Brand Personality memiliki nilai sig. 0,834 $>0,05$ dan nilai thitung $-0,210<t_{\text {tabel }} 1,97852$, sehingga dapat disimpulkan bahwa $\mathrm{H} 0$ diterima dan $\mathrm{H} 1$ 
ditolak yang berarti tidak terdapat pengaruh secara parsial dimensi $\mathrm{X}_{2}$ (Brand Personality) terhadap Y (Keputusan Menginap) di Hotel X. Hal ini disebabkan karena, konsumen tidak memutuskan untuk menginap karena Hotel $\mathrm{X}$ terkenal/ ternama, atau karena ingin memiliki kebangaan karena telah menginap di Hotel Aston, tetapi lebih karena alasan lain yang dapat dijelaskan variabel lainnya.

Dimensi $\mathrm{X}_{3}$ Brand Association memiliki nilai sig. $0,000<0,05$ dan nilai $t_{\text {hitung }}$ $5,008>t_{\text {tabel }} 1,97852$, sehingga dapat disimpulkan bahwa $\mathrm{H} 0$ ditolak dan $\mathrm{H} 1$ diterima yang berarti terdapat pengaruh secara parsial dimensi $\mathrm{X}_{3}$ (Brand Association) terhadap Y (Keputusan Menginap). Hal ini disebabkan dalam menentukan keputusan menginap di Hotel X, konsumen memperhatikan Brand Association dari Hotel X. Dimensi $\mathrm{X}_{3} \quad$ (Brand Association) berperan dalam menentukan keputusan menginap di Hotel X.

Dimensi $\mathrm{X}_{4}$ Brand Attitude and Behavior memiliki nilai sig. 0,646>0,05 dan nilai $\mathrm{t}_{\text {hitung }} 0,460<\mathrm{t}_{\text {tabel }} 1,97852$, sehingga dapat disimpulkan bahwa $\mathrm{H} 0$ diterima dan $\mathrm{H} 1$ ditolak yang berarti tidak terdapat pengaruh secara parsial dimensi $\mathrm{X}_{4}$ (Brand Attitude and Behavior) terhadap Y (Keputusan Menginap) di Hotel X. Hal ini dapat ditarik kesimpulan bahwa Hotel X kurang baik dalam memberikan layanan kepada konsumen, sehingga sebagian konsumen belum yakin dalam memutuskan untuk menginap dilihat dari Brand Attitude and Behavior yang diberikan Hotel $X$, sehingga keputusan menginap lebih dipengaruhi oleh alasan lain selain alasan Brand Attitude and Behavior.

Dimensi $\mathrm{X}_{5}$ Brand Benefit and Competence memiliki nilai sig. $0,000<0,05$ dan nilai $t_{\text {hitung }} 3,724>t_{\text {tabel }} 1,97852$, sehingga dapat disimpulkan bahwa $\mathrm{H} 0$ ditolak dan $\mathrm{H} 1$ diterima yang berarti terdapat pengaruh secara parsial dimensi $\mathrm{X}_{5}$ (Brand Benefit and Competence) terhadap Y (Keputusan Menginap). Hal ini disebabkan dalam menentukan keputusan menginap di Hotel X, konsumen memperhatikan Brand Benefit and Competence yang terdiri dari harga yang ditawarkan, kompeten, dan sebanding dengan layanan yang didapatkan dari Hotel X. Dimensi $\mathrm{X}_{5}$ (Brand Benefit and Competence) berperan dalam menentukan keputusan menginap di Hotel X.

\section{Uji F}

Dasar pengambilan keputusan untuk uji f menurut Ghozali (2018) adalah :

1. Berdasarkan Tingkat Signifikansi

- Apabila tingkat signifikansi (Sig.) < 0,05, maka hipotesis (H1) diterima. Artinya variabel $\mathrm{X}$ memiliki pengaruh signifikan terhadap variabel $\mathrm{Y}$.

- Apabila tingkat signifikansi (Sig.) > dari 0,05, maka hipotesis (H1) ditolak. Artinya variabel $\mathrm{X}$ tidak memiliki pengaruh signifikan terhadap variabel Y.

2. Berdasarkan $\mathrm{F}_{\text {tabel }}$

Menurut Sarwono (2013), rumus mencari $F_{\text {tabel }}$ adalah :

$\mathbf{k}-\mathbf{1} ; \mathbf{n}-\mathbf{k}$

Dimana :

$\mathrm{k}=$ Jumlah variabel

$\mathrm{n}=$ Jumlah responden / sampel penelitian

Sehingga, $\mathrm{f}_{\text {tabel }}$ adalah : 6-1; 135-5

$=5 ; 130$

$=(2,28)$

- Apabila $F_{\text {hitung }}>$ atau sama dengan 2,28; maka H1 diterima. Artinya variabel $\mathrm{X}$ secara bersama-sama memiliki pengaruh signifikan terhadap variabel Y.

- Apabila $F_{\text {hitung }}<2.28$; maka H1 ditolak. Artinya variabel $\mathrm{X}$ secara bersamasama tidak memiliki pengaruh signifikan terhadap variabel Y.

Berikut adalah hasil penghitungan uji F dengan menggunakan SPSS :

Tabel 10. Hasil Perhitungan Uji F 


\begin{tabular}{|c|c|c|c|c|c|c|}
\hline & & & OWA & & & \\
\hline Mode & & Sum of Soures & df & Mean Square & $F$ & Sig. \\
\hline 1 & Revression & 538.992 & 5 & 107.798 & 47.086 & $.000^{\circ}$ \\
\hline & Residual & 295.334 & 129 & 2.289 & & \\
\hline & Total & 834.326 & 134 & & & \\
\hline
\end{tabular}

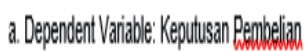

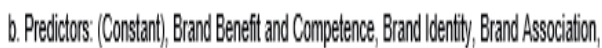

\section{Brand Pessonality, Brand Aftitude and Behavior}

Sumber : Data diolah peneliti dengan SPSS 25, 2020

Berdasarkan output di atas diketahui nilai signifikansi untuk pengaruh variabel $\mathrm{X}$ secara simultan terhadap Y $0,000<0,05$ dan nilai $\mathrm{F}$ hitung 47,086 > F tabel 2,28, sehingga dapat disimpulkan bahwa $\mathrm{H} 1$ diterima yang berarti terdapat pengaruh variabel $\mathrm{X}$ (brand image) secara simultan terhadap $\mathrm{Y}$ (Keputusan Menginap) di Hotel X. Sehinga ditarik kesimpulan bahwa secara simultan atau menyeluruh konsumen tertarik dan memutuskan untuk menginap dikarenakan brand image dari Hotel $\mathrm{X}$, walaupun secara parsial ada beberapa variabel yang tidak mempengaruhi tidak menghalami konsumen untuk tetap memilih Hotel $\mathrm{X}$ sebagai akomodasi mereka.

\section{Analisis Regresi Berganda}

\section{Tabel 11. Analisis Linier Berganda}

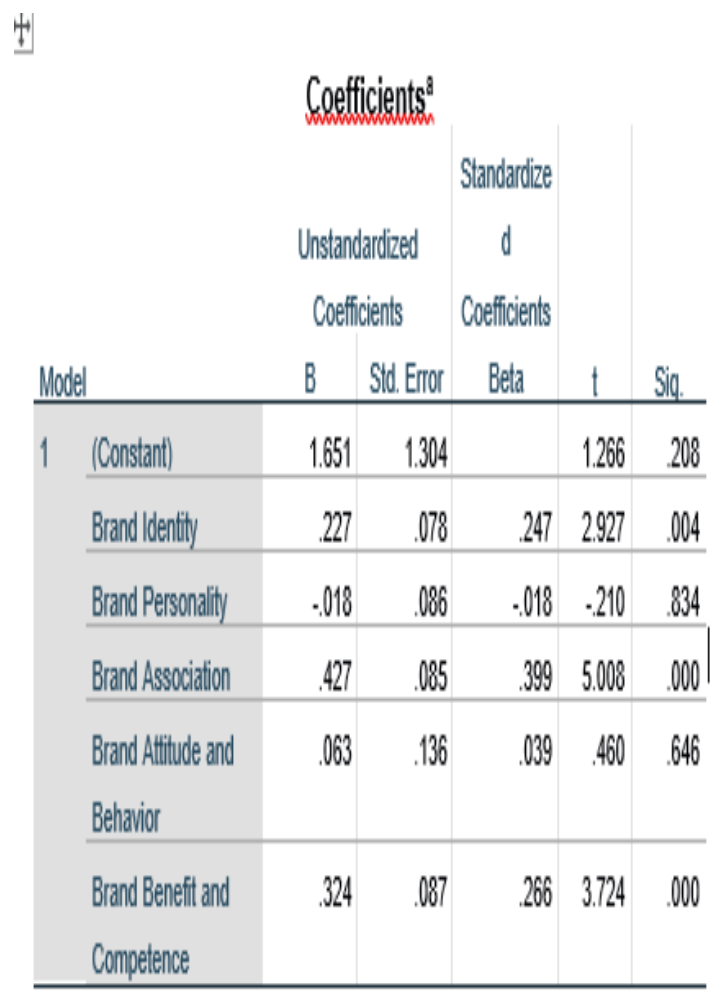

\section{a. Dependent Varioble: Kepotisan Penbelian}

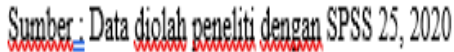

Berdasarkan tabel coefficients, dapat disusun persamaan analisis regresi berganda seperti dibawah ini :

$\mathrm{Y}=1,651+0,227 \mathrm{x} 1+(-0,018) \mathrm{x} 2+0,427 \mathrm{x} 3$ $+0,063 \times 4+0,324 \times 5$

\section{Atau}

Keputusan Menginap $=1,651+0,227$.Brand Identity - 0,018. Brand Personality $+0,427$ Brand Association + 0,063 Brand Attitude and Behavior $+0,324$ Brand Benefit and Competence

$\mathrm{Y}=2,674$

Melalui uji analisis regresi linear berganda ini, dapat ditarik kesimpulan sebagai berikut:

a. Nilai konstanta adalah 1,651. Hal ini diartikan apabila semua variabel bebas bernilai 0 (nol) maka nilai variabel terikat adalah sebesar 1,651.

b. Koefisien regresi Brand Identity bernilai positif artinya pada saat adanya peningkatan alasan Brand Identity, maka keputusan menginap di Hotel $\mathrm{X}$ juga akan meningkat. Sebaliknya apabila ada penurunan untuk alasan tersebut, maka 
keputusan menginap di Hotel $\mathrm{X}$ juga akan menurun. Nilai koefisien Brand Identity adalah 0,227. Hal ini diartikan sebagai setiap kenaikan alasan brand identity 1 (satu) satuan maka keputusan menginap konsumen akan naik sebesar 0,227 dengan asumsi bahwa variabel bebas yang lain dari model regresi adalah tetap.

c. Koefisien regresi Brand Personality bernilai negatif artinya, menunjukan adanya perlawanan arah hubungan. Pada saat adanya peningkatan untuk alasan Brand Personality, maka minat keputusan menginap di Hotel $X$ akan menurun. Nilai koefisien Brand Personality adalah 0,018. Hal ini diartikan sebagai setiap kenaikan alasan Brand Personality 1 (satu) satuan maka minat membeli konsumen akan turun sebesar 0,018. dengan asumsi bahwa variabel bebas yang lain dari model regresi adalah tetap.

d. Koefisien regresi Brand Association bernilai positif artinya pada saat adanya peningkatan alasan Brand Association, maka keputusan menginap di Hotel X juga akan meningkat. Sebaliknya apabila ada penurunan untuk alasan tersebut, maka keputusan menginap di Hotel $\mathrm{X}$ juga akan menurun. Nilai koefisien Brand Association adalah 0,427. Hal ini diartikan sebagai setiap kenaikan alasan Brand Association 1 (satu) satuan maka keputusan menginap konsumen akan naik sebesar 0,427 dengan asumsi bahwa variabel bebas yang lain dari model regresi adalah tetap.

e. Koefisien regresi Brand Attitude and Behavior bernilai positif artinya pada saat adanya peningkatan alasan Brand Attitude and Behavior, maka keputusan menginap di Hotel $X$ juga akan meningkat. Sebaliknya apabila ada penurunan untuk alasan tersebut, maka keputusan menginap di Hotel $X$ juga akan menurun. Nilai koefisien Brand Attitude and Behavior adalah 0,063. Hal ini diartikan sebagai setiap kenaikan alasan Brand Attitude and Behavior 1 (satu) satuan maka keputusan menginap konsumen akan naik sebesar 0,063 dengan asumsi bahwa variabel bebas yang lain dari model regresi adalah tetap.
Koefisien regresi Brand Benefit and Competence bernilai positif artinya pada saat adanya peningkatan alasan Brand Benefit and Competence, maka keputusan menginap di Hotel X juga akan meningkat. Sebaliknya apabila ada penurunan untuk alasan tersebut, maka keputusan menginap di Hotel $X$ juga akan menurun. Nilai koefisien Brand Benefit and Competence adalah 0,324. Hal ini diartikan sebagai setiap kenaikan alasan Brand Benefit and Competence 1 (satu) satuan maka keputusan menginap konsumen akan naik sebesar 0,324 dengan asumsi bahwa variabel bebas yang lain dari model regresi adalah tetap.

\section{SIMPULAN}

- Melalui uji t, diketahui beberapa dimensi dalam brand image berpengaruh secara parsial terhadap keputusan menginap. Dimulai dari brand identity memiliki nilai sig. $0,004<0,05$, brand association memiliki nilai sig. $0,000<0,05$, brand benefit and competence memiliki nilai sig. $0,000<0,05$. Sehingga dapat disimpulkan bahwa dari 5 dimensi, 3 dimensi memiliki pengaruh secara parsial terhadap keputusan menginap di Hotel X.

- Sementara 2 (dua) indikator lain yang tidak berpengaruh, yaitu brand personality memiliki nilai sig. 0,834>0,05, dan brand attitude and behavior 0,646>0,05, sehingga dapat dinyatakan bahwa dalam kasus Hotel $\mathrm{X}$ tidak mempengaruhi konsumen untuk menginap. Hal ini dikarenakan Hotel masih kurang dalam memberikan brand image yang baik dan informasi yang kurang sesuai terkait dengan alasan brand personality dan brand attitude and behavior.

- Tetapi, jika dilakukan secara simultan atau secara bersama-sama, semua indikator dalam brand image mempengaruhi keputusan menginap konsumen. Dari hal ini menunjukan bahwa alasan konsumen menginap di Hotel bukan karena satu alasan, tetapi seluruh indikator dapat menjadi alasan yang saling menguatkan jika diuji secara bersama-sama. Melalui hasil penelitian ini, penulis dapat menarik 
kesimpulan bahwa dalam alasan keputusan konsumen yang menginap di Hotel X dikarenakan beberapa alasan yaitu brand personality, brand brand attitude and behaviour, dan brand benefit and competence berpengaruh dalam menentukan keputusan tersebut, terlebih dari itu secara keseluruhan aspek tersebut mempengaruhi keputusan konsumen untuk menginap. Dapat disimpulkan Hotel X berhasil dalam memberikan brand image yang baik sehingga masyarakat percaya untuk menggunakan Hotel $\mathrm{X}$ sebagai tempat peristirahatan mereka.

\section{DAFTAR PUSTAKA}

Adiwidjaja, Adrian Junio., \& Tarigan, Zeplin Jiwa Husada (2017). Pengaruh Brand Image dan Brand Trust Terhadap Keputusan Pembelian Sepatu Converse. Skripsi. Surabaya : Fakultas Ekonomi. Universitas Kristen Petra.

Adiwiyah, S, R., \& Wulandari, A. (2016). Pengaruh Brand Image Terhadap Keputusan Pembelian Pada Chatime. Skripsi. Bandung : Fakultas Menejemen Pemasaran. Universitas Telkom.

Arikunto, S. (2013). Prosedur Penelitian Suatu Pendekatan Praktik. Jakarta: Rineka Cipta

Badan Pusat Statistika (2020). Jumlah akomodasi kamar dan tempat tidur yang tersedia pada hotel bintang menurut provinsi 2000-2018. Diakses pada 10 Februari 2020. 18.12 WIB. Dari

https://www.bps.go.id/dynamictable/ 2015/12/28/1096/jumlah-akomodasikamar-dan-tempat-tidur-yangtersedia-pada-hotel-bintang-menurutprovinsi-2000-2018.html

Bilson, Simamora. (2011). Memenangkan Pasar dengan Pemasaran Efektif dan Profitabel. Jakarta: PT. Gramedia Pustaka Utama

Ghozali. Imam. (2018). Aplikasi Multivariate dengan program IBM SPSS 25. Semarang : Badan Penerbit Universitas Diponegoro.
Hair, Jr et.al. (2010). Multivariate Data Analysis (7th ed). United States : Pearson

Irwansyah, Ruri Indra. (2017). Pengaruh Kualitas Pelayanan, Harga, Dan Promosi Terhadap Kepuasan Pelanggan dan Minat Menginap Kembali. Skripsi. Purwokerto : Fakultas Ekonomi dan Bisnis. Universitas Muhammadiyah.

Juwitasari, Amalia. (2014). Pengaruh Media Advertising Above The Line Terhadap Keputusan Menginap Di Aston Braga Hotel and Residence Bandung. Skripsi. Bandung : Fakultas Pendidikan Ilmu Pengatahuan Sosial. Universitas Pendidikan Indonesia.

Kevin, S. (2018). Pengaruh Brand Image Terhadap Keputusan Pembelian di Dunkin Donuts, Metro Permata, Tangerang. Jakarta. Skripsi. Prodi Hospitality dan Pariwisata.Universitas Bunda Mulia.

Kotler, P., \& G. Armstrong. (2016). Principle of Marketing Edisi 15. Ebook: Pearson

Kotler,P., \& Keller, Kevin L. (2013) Manajemen Pemasaran. Jilid Kedua. Jakarta: Erlangga

Kurniawan, Hakam. (2016). Resort Di Kawasan Hutan Mangrove Rembang (dengan Penekananarsitektur NeoVernakular). Skripsi. Surakarta. Fakultas Teknik. Universitas Muhammadiyah Surakarta.

Marsiani, Ni Luh Gede. (2017). Pengaruh Tingkat Hunian Kamar Terhadap Pendapatan Makanan dan Minuman di Grand Aston Grand Bali Beach Resort. Jurnal Kepariwisataan dan Hospitalitas. Vol. 1, No. 2, 2-3.

Permana, Sandi Indra. (2016). Pengaruh Kualitas Produk dan Brand Ambassador Terhadap Citra Merek Serta Dampaknya Terhadap Keputusan Pembelian Pada Distro Relic Syndicate. Skripsi. Bandung. Fakultas Ekonomi dan Bisnis. Universitas Pasundan.

Pontoh, Y.G. (2016). Pengaruh Celebrity Endorser (Pevita Pearce) Terhadap Minat Beli Konsumen Pada Produk Garnier BB Cream Di Fakultas 
Ekonomi dan Bisnis Universitas Lampung. Skripsi. Lampung. Fakultas Ekonomi dan Bisnis. Universitas Lampung.

Pratiwi, Putri (2017). Pengaruh Citra Merek Terhadap Proses Keputusan Pembelian Konsumen Hotel Aston Di Bandung. Skripsi. Administrasi Bisnis. Universitas Telkom.

Said, A. M. (2015). Mendidik Remaja Nakal. Jakarta: Semesta Hikmah.

Sarwono, Jonathan. (2006). Metode Penelitian Kuantitatif dan Kualitatif. Yogyakarta: Graha Ilmu

Sarwono, Jonathan. (2013). Statistik Multivariat Aplikasi Untuk Riset Skripsi. Yogyakarta: Andi Offset.

Sciffman, L. G. (2019). Consumer Behavior. Twelfth Edition. Harlow: Pearson Education Limited

Sekaran, Uma, \& Roger Bougie (2016). Research Methods For Business: A Skill Building Approach, 7th Edition. Ebook: Wiley

Siregar. (2013). Cara Mudah Menyusun Skripsi, Tesis, dan Disertasi Cetakan Ke-1. Bandung: CV. Alfabeta.

Sugiyono. (2015). Statistik Untuk Penelitian. Bandung: CV. Alfabeta.

Sugiyono. (2018). Metode Penelitian Kuantitatif, Kualitatif, dan $R \& D$. Bandung: Alfabeta.

Tjiptono, Fandy. (2011). Prinsip-prinsip Total Quality Service. Yogyakarta: Andi Offset.

Tjiptono, Fandy. (2014). Pemasaran Jasa Prinsip, Penerapan, dan Penelitian. Yogyakarta: Andi Offset.

Travel Kompas (2018, 02 Agustus). Sepotong Sejarah Hotel Indonesia, Dibangun Karena Asian Games. Diakses pada 03 Maret 2020, 13.45 WIB. Dari https://travel.kompas.com/read/2018/ $\underline{08 / 02 / 121500527 / \text { sepotong-sejarah- }}$ hotel-indonesia-dibangun-karenaasian-games?page $=$ all

Zainudin, Ega Wibisono. (2018). Pengaruh Persepsi Konsumen Tentang Brand Image (Citra Merek), Harga, dan Promosi Terhadap Keputusan Pembelian Motor Honda Dengan Memperhatikan Kepuasan Konsumen di PT. Nusatara Surya Sakti Kedaton
Bandar Lampung. Skripsi. Fakultas Keguruan dan Ilmu Pendidikan. Universitas Lampung. 